\title{
Unexpected Histopathological Diagnoses in Acute Appendicitis Specimens: A Retrospective Analysis of 2076 Patients
}

\section{Akut Apandisit Spesmenlerinde Beklenmeyen Histopatolojik Tanılar: 2076 Hastanın Retrospektif Analizi}

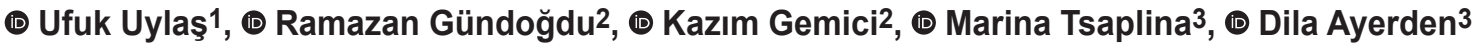 \\ ${ }^{1}$ Gaziantep Dr. Ersin Arslan Training and Research Hospital, Clinic of Gastroenterology Surgery, Gaziantep, Turkey \\ ${ }^{2}$ Gaziantep Dr. Ersin Arslan Training and Research Hospital, Clinic of General Surgery, Gaziantep, Turkey \\ ${ }^{3}$ Gaziantep Dr. Ersin Arslan Training and Research Hospital, Clinic of Pathology, Gaziantep, Turkey
}

\section{HIIIII| ABSTRACT}

\begin{abstract}
Aim: Acute appendicitis is the most common cause of emergency abdominal surgery in the world. Although the etiology of appendicitis is still not fully known, possible causes include lumen obstruction. Fecaloid and lymphoid hyperplasia are the most common causes of lumen obstruction. However, some rare conditions may cause acute appendicitis by causing lumen obstruction. Here, we aimed to present the pathology results of 2076 patients operated due to acute appendicitis in our hospital and the unexpected histopathological findings in the light of the literature.

Method: Patients who were emergently operated with diagnosis of appendicitis between January 2016 and February 2020 in Gaziantep Dr. Ersin Arslan Training and Research Hospital were retrospectively screened. Incidental appendectomies were excluded. Data of 2076 patients were reached. Gender, age, and pathology results of the patients were analyzed. Pathology preparations were reassessed by two pathologists. Pathology results were analyzed under two categories as general findings and unexpected findings. Fisher's chi-square test was used for statistical analysis.

Results: A total of 2076 patients were included in the study and analyzed. Of the patients, 1368 (66\%) were man, 708 (34\%) were woman, and the mean age was $33 \pm 12.9$ years. Acute appendicitis was found in 1309 (63.1\%) patients, gangrenous-perforated appendicitis in 305 (14.7\%) patients, negative appendectomy in 105 (5.1\%) patients, phlegmonous appendicitis in 32 (1.5\%) patients, and unexpected pathological findings in 62 (3\%) patients. Among the unexpected pathological findings were fibrous obliteration in 31 (50\%) patients, mucosal hyperplasia in 8 (13\%) patients, appendicular diverticulitis in $7(11.3 \%)$ patients, retention cyst in $5(8.1 \%)$ patients, mucinous cystadenoma in 3 (4.8\%) patients, well-differentiated neuroendocrine tumor in 2 (3.2\%) patients, eosinophilic infiltration in 2 (3.2\%) patients, foreign body reaction in 2 (3.2\%) patients, granulomatous appendicitis in $1(1.6 \%)$ patient, and parasitic infestation was detected in $1(1.6 \%)$ patient.
\end{abstract}

Conclusion: Unexpected histopathological findings are rare in appendectomy specimens and these diagnoses help guide the patient's treatment. Keywords: Appendicitis, neuroendocrine neoplasm, mucocele, adenocarcinoma, carcinoid

\section{|||||||||| ÖZ}

Amaç: Akut apandisit dünya üzerinde en sık acil karın ameliyatıdır. Apandisitin etiyolojisi hala tam olarak bilinmemekle birlikte olası nedenler arasında lümen obstrüksiyonu yer alır. Fekaloit ve lenfoid hiperplazi lümen obstrüksiyonuna neden olan en yaygın nedenlerdir. Ancak bazı nadir durumlar da lümen obstrüksiyonu yaparak akut apandisite neden olabilmektedir. Biz burada hastanemizde akut apandisit tanısıyla opere edilen 2076 hastanın patoloji sonuçlarını ve bunlar arasında beklenmeyen histopatolojik bulguları literatür eşliğinde sunmayı amaçladık.

Yöntem: Gaziantep Dr. Ersin Arslan Eğitim ve Araştırma Hastanesi'nde Ocak 2016-Şubat 2020 tarihleri arasında akut apandisit tanısıyla acil opere edilen hastalar retrospektif olarak tarandı. İnsidental apendektomiler çalışma dışı bırakıldı. Toplam 2076 hastanın verisine ulaşıldı. Hastaların cinsiyet, yaş ve patoloji sonuçları analiz edildi. Patoloji preparatları iki patolog tarafından tekrar değerlendirildi. Patoloji sonuçları genel bulgular ve beklenmeyen bulgular olarak iki kategori altında incelendi. İstatistiksel analizde Fisher's ki-kare testi kullanıldı. 


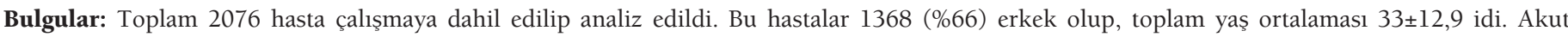
apandisit 1309 (\%63,1), gangrenöz-perfore apandisit 305 (\%14,7), negatif apendektomi 105 (\%5,1), flegmanöz apandisit 32 (\%1,5), beklenmeyen patolojik bulgular ise $62(\% 3)$ hastada saptandi. Beklenmeyen patolojik bulgular içerisinde, 31 (\%50) hastada fibröz obliterasyon 8 (\%13) hastada mukozal hiperplazi, 7 (\%11,3) hastada apendiküler divertikülit, $5(\% 8,1)$ hastada retansiyon kisti $3(\% 4,8)$ hastada müsinöz kistadenom 2 (\%3,2) hastada iyi defansiye nöroendokrin tümör, $2(\% 3,2)$ hastada eozinofilik infiltrasyon, $2(\% 3,2)$ hastada yabancı cisim reaksiyonu, 1 (\%1,6) hastada granülomatöz apandisit ve $1(\% 1,6)$ hastada parazit enfestasyonu saptandı.

Sonuç: Apendektomi spesmenlerinde beklenmedik histopatolojik bulgular nadir olup, bu tanılar hastanın tedavisini yönlendirmeye yardımcı olmaktadırlar.

Anahtar Kelimeler: Apandisit, nöroendokrin neoplazm, mukosel, adenokarsinom, karsinoid

\section{Introduction}

Acute appendicitis remains one of the most common causes of emergency abdominal surgeries in the world. Appendectomy is performed in patients with suspected or definite acute appendicitis. Appendectomy not only removes the appendix but also prevents mortal complications such as perforation, plastron and sepsis. ${ }^{1}$ While the risk of development of acute appendicitis is higher in men, women are more exposed to appendectomy. The incidence of acute appendicitis is 8.6\% in men and $6.9 \%$ in women. The appendectomy rate is $12 \%$ in men and $23 \%$ in women. ${ }^{2}$ Appendicitis can be seen in all age groups but is often seen between 10-20 years of age. ${ }^{3}$

Although the etiology of appendicitis is still unknown, lumen obstruction is one of the possible causes. ${ }^{4}$ Lumen obstruction prevents the discharge of mucosal secretions, resulting in increased lumen intra-pressure. As a result of increased pressure, venous and lymphatic drainage deteriorates, causing necrosis and perforation. ${ }^{5}$ Fecaloid and lymphoid hyperplasia are the most common causes of lumen obstruction. However, some rare cases can cause an acute appendicitis by causing lumen obstruction. Among these are enterobiasis, ascariasis, tapeworm, actinomycosis, schistosomiasis, amebiasis, carcinoid tumor, adenocarcinoma, endometriosis, granulomatous diseases, gastrointestinal stromal tumors and mucocele. ${ }^{6}$

There are many studies reporting unexpected histopathological findings following examination of appendectomy specimens. ${ }^{7,8,9}$ In this way, bening and malignant tumors and infectious diseases can be diagnosed early and treated. In order to emphasize that unexpected histopathological findings are important in appendectomy specimens, we conducted a retrospective analysis of appendectomy specimens in our hospital. We aimed to present the pathology results of 2076 patients with acute appendicitis in our hospital and the unexpected histopathological findings among them with the literature.

\section{Materials and Methods}

Patients who were admitted to the emergency service with the diagnosis of acute appendicitis between January 2016 and February 2020 in Gaziantep Dr. Ersin Arslan Training and Research Hospital were retrospectively screened. Incidental appendectomies were excluded. Data of a total of 2076 patients were accessed. The gender, age and pathology results of the patients were analyzed. Negative appendectomy and unexpected histopathological findings by gender were evaluated separately. The distribution of pathological findings by age was analyzed. Pathology preparations were re-examined by two pathologists (MT, DA). Pathology results were analyzed under two categories as general findings and unexpected findings. Acute, gangrenous-perforated and phlegmatous appendicitites were included in the group of general pathological findings. Appendicular diverticulitis, eosinophilic infiltration, granulomatous appendicitis, fibrous obliteration, mucosal hyperplasia, mucocele, mucinous cystadenoma, mucinous neoplasia, neuroendocrine tumor, parasite infestation and foreign body reaction were included in the group of unexpected pathological findings. In statistical analysis, quantitative variables were expressed as mean \pm standard deviation, median, minimum-maximum and range. Qualitative variables were reported as number and percentage (\%). Fisher's chi-square test was used to compare qualitative variables. A p value less than 0.05 was considered statistically significant.

\section{Results}

A total of 2076 patients were included in the study and analyzed. Of the patients, 1368 (66\%) were man, 708 (34\%) were woman, and the mean age was $33 \pm 12.9$ years. The majority of the patients were between the ages of 21-30 (36\%) years and $1.2 \%$ of the patients were over 70 years (Table 1). Acute appendicitis was detected in 1309 (63.1\%) patients, gangrenous-perforated appendicitis in 305 (14.7\%) patients, lymphoid hyperplasia in 263 (12.7\%) patients, negative appendectomy in 105 (5.1\%) patients, phlegmatous appendicitis in 32 (1.5\%) patients, unexpected pathological findings in $62(3 \%)$ patients. Among the unexpected pathological findings, fibrous obliteration was found in 31 (50\%) patients, appendicular diverticulitis in 7 (11.3\%) patients, retention cyst in $5(8.1 \%)$ patients, mucinous 
cystadenoma in $3(4.8 \%)$ patients, well-differentiated neuroendocrine tumor in $2(3.2 \%)$ patients, eosinophilic infiltration in $2(3.2 \%)$ patients, foreign body reaction in 2 (3.2\%) patients, granulomatous appendicitis in 1 (1.6\%) patient, and parasite infestation in 1 (1.6\%) patient (Table 2).

Table 1. Demographic characteristics of patients undergoing appendectomy

\begin{tabular}{|c|c|}
\hline Features of patients & Result \\
\hline Number of patients & 2076 \\
\hline \multicolumn{2}{|l|}{ Gender } \\
\hline Male & 1368 \\
\hline Female & 708 \\
\hline \multicolumn{2}{|l|}{ Features about age } \\
\hline All patients & $33.01 \pm 12.9$ \\
\hline Males & $31.5 \pm 11.8$ \\
\hline Females & $35.96 \pm 14.3$ \\
\hline \multicolumn{2}{|c|}{ Distribution of patients by age } \\
\hline $15-20$ & 320 \\
\hline $21-30$ & 743 \\
\hline $31-40$ & 508 \\
\hline $41-50$ & 286 \\
\hline $51-60$ & 128 \\
\hline $61-70$ & 66 \\
\hline$>70$ & 25 \\
\hline \multicolumn{2}{|c|}{$\begin{array}{l}\text { Distribution of patients with negative } \\
\text { appendectomy by age }\end{array}$} \\
\hline All patients & 105 \\
\hline Males & $66(4.8 \%)$ \\
\hline Females & $39(5.5 \%)$ \\
\hline $15-20$ & 13 \\
\hline $21-30$ & 34 \\
\hline $31-40$ & 23 \\
\hline $41-50$ & 20 \\
\hline $51-60$ & 10 \\
\hline $61-70$ & 3 \\
\hline$>70$ & 2 \\
\hline
\end{tabular}

Acute appendicitis was detected in 890 (65.1\%) of male and 419 (59.2\%) of female patients. The frequency of acute appendicitis was significantly higher in men $(\mathrm{p}=0.01)$. Perforated appendicitis was detected in 196 (14.3\%) of male and 109 (15.4\%) of female patients. Perforated appendicitis was more common in women, but there was no statistical significance between genders $(\mathrm{p}=0.51)$. Negative appendectomy was detected in $66(4.8 \%)$ of male and 39 (5.5\%) of female patients. Negative appendectomy was more common in women, but there was no statistical significance between genders $(\mathrm{p}=0.53)$ (Table 3$)$. The majority of patients with negative appendectomy was between the ages of 21-30 years.

Unexpected pathological findings were found in $62(3 \%)$ patients, $38(1.8 \%)$ of whom were male and $24(1.2 \%)$ of whom were female. Fibrous obliteration was detected in $31(1.5 \%)$ patients, mucosal hyperplasia in $8(0.9 \%)$ patients, appendicular diverticulitis in $7(0.3 \%)$ patients, retention cyst (mucocele) in $5(0.2 \%)$ patients, mucinous

Table 2. Histopathological findings of appendectomy specimens

$\begin{array}{ll}\text { Histopathological findings } & \text { Total } \\ \text { Acute appendicitis } & 1309(63.1 \%) \\ \text { Gangrenous-perforated appendicitis } & 305(14.7 \%) \\ \text { Lymphoid hyperplasia } & 263(12.7 \%) \\ \text { Negative appendectomy } & 105(5.1 \%) \\ \text { Phlegmatous appendicitis } & 32(1.5 \%) \\ \text { Unexpected histopathological findings } & 62(3 \%) \\ \text { Fibrous obliteration } & 31(50 \%) \\ \text { Mucosal hyperplasia } & 8(13 \%) \\ \text { Appendicular diverticulitis } & 7(11.3 \%) \\ \text { Retention cyst } & 5(8.1 \%) \\ \text { Mucinous cystadenoma } & 3(4.8 \%) \\ \text { Neuroendocrine tumor, well differentiated } & 2(3.2 \%) \\ \text { Eosinophilic infiltration } & 2(3.2 \%) \\ \text { Foreign body reaction } & 2(3.2 \%) \\ \text { Granulomatous appendicitis } & 1(1.6 \%) \\ \text { Parasite infestation } & 1(1.6 \%)\end{array}$

Table 3. Comparison of histopathological findings by gender

$\begin{array}{llll} & \text { Male }(\mathbf{n}=1368) & \text { Female }(\mathbf{n}=708) & \text { Statistical analysis } \\ \text { Acute appendicitis } & 890(65.1 \%) & 419(59.2 \%) & \mathrm{p}<0.05 \\ \text { Perforated appendicitis } & 196(14.3 \%) & 109(15.4 \%) & \mathrm{p}>0.05 \\ \text { Negative appendectomy } & 66(4.8 \%) & 39(5.5 \%) & \end{array}$


cystadenoma in $3(0.1 \%)$ patients, well-differentiated neuroendocrine tumor in $2(0.1 \%)$ patients, eosinophilic infiltration in $2(0.1 \%)$ patients, foreign body reaction in 2 $(0.1 \%)$ patients, granulomatous appendicitis in $1(0.05 \%)$ patient, and parasite infestation in $1(0.05 \%)$ patient.

\section{Discussion}

The incidence of acute appendicitis is higher in men. The differential diagnosis includes normal menstruation, dysmenorrhea, ovarian torsion, ectopic pregnancy, and pelvic inflammatory disease, which are especially seen in premenopausal women. ${ }^{10}$ This explains why women are mostly exposed to negative appendectomy. There are studies reporting the negative appendectomy rate as $6.3-22.8 \%$ in the literature. ${ }^{1,11}$ In our study, negative appendectomy was found in $5.1 \%$ of the patients, and it was found more in women who were operated, but the difference was not statistically significant $(p=0.53)$. The lower rates of negative appendectomy compared to the literature was thought to be a result of the widespread use of ultrasound and computed tomography, which have become routine in the preoperative period.

Although rare, different pathologies of the appendix can be encountered in patients who have been operated with a prediagnosis of acute appendicitis. These include congenital anomalies such as appendix duplication and appendix vermiformis agenesis. ${ }^{12,13}$ No congenital anomalies were found in our clinical series. Unexpected histopathologies can be detected in appendectomy specimens. In a literature review, the rate of unexpected histopathological diagnoses was reported as $1.7 \%$, and the rate of primary and secondary adenocarcinoma and mucinous cystadenocarcinoma of the appendix was reported as $0.03 \% .{ }^{6}$ In our study, the rate of unexpected histopathological findings was 3\% and primary and secondary adenocarcinoma and mucinous cystadenocarcinoma of the appendix were not detected.

Fibrous obliteration is thought to develop as a result of neurogenic proliferation and is also referred as neurogenic appendicopathy and appendiceal neuroma. In addition, the molecular mechanism in its pathogenesis is unknown. It is thought to occur as a result of obstruction of the lumen of the appendix with fibrous tissue secondary to hyperplasia of neuroendocrine cells. Fibrous obliteration is seen in $9.7 \%$ of incidental appendectomy specimens. ${ }^{14}$ In acute appendicitis series, it is seen at a rate of 0.8-4.5\% and constitutes $27.1-65 \%$ of unexpected histopathological findings. ${ }^{15,16}$ In our study, fibrous obliteration was detected in $31(1.5 \%)$ patients and constituted $50 \%$ of unexpected histopathological findings.

Appendicular diverticulum is an extremely rare condition. Its incidence is $0.004-2.1 \%$ in appendectomy specimens, while it is $0.2-0.6 \%$ in routine autopsy series. ${ }^{17}$ Appendicular diverticulum can be acquired or congenital. Acquired diverticula are mostly seen in patients aged $>30$ years old. In another series in which appendectomy was performed due to acute appendicitis, appendicular diverticulum was detected at a rate of $0.8 \%$, and diverticulitis was found in $61.5 \%$ of them. ${ }^{18}$ In the presence of diverticulum, the risk of perforation and mortality is higher than acute appendicitis without diverticulum. ${ }^{19}$ In our study, appendicular diverticulum was detected in $7(0.3 \%)$ patients, appendicular diverticulitis was detected in $6(86 \%)$ patients, and no perforation was observed.

Appendiceal mucocele was first described by Rokitansky in $1842^{20}$. It occurs as a result of obstructive dilatation of the appendix and mucoid material filling the lumen. Appendiceal mucocele is rare, with an incidence of 0.07$0.63 \%$ in appendectomy specimens. ${ }^{21}$ Histopathologically, there are four subtypes. These are retention cyst, mucosal hyperplasia, mucinous cystadenoma and mucinous cystadenocarcinoma. ${ }^{22}$ When total excision is performed without perforation in the benign forms of retention cyst, mucosal hyperplasia and mucinous cyst adenoma, 5-year survival is $100 \%{ }^{23}$ In our study, mucosal hyperplasia was detected in $8(0.4 \%)$, retention cyst (mucocele) in $5(0.2 \%)$ and mucinous cystadenoma in $3(0.1 \%)$ patients, and mucinous cystadenocarcinoma was not detected.

Mucosal hyperplasia was first described by MacGillivray ${ }^{24}$ in 1972 as mucosal metaplasia associated with colon cancer. Thereupon, in another study, appendices in the specimens of patients who underwent ileocolectomy were examined. Mucosal hyperplasia was found in $30 \%$ of adenocarcinomas, $11.8 \%$ of adenomatous polyps, and $6.5 \%$ of non-neoplastic specimens. ${ }^{25}$ In our study, mucosal hyperplasia was detected in $8(0.4 \%)$ patients, and it constituted $13 \%$ of unexpected histopathological findings. Colonoscopy was performed in these patients for malignancy screening and to detect accompanying colon pathologies, and no evidence of malignancy was found.

Granulomatous appendicitis is a rare condition in appendectomy specimens. Granulomatous infection of the appendix was first reported in 1953 by Meyerding and Bertram $^{26}$ as a finding of Chron's disease. Granulomatous appendicitis is detected at a rate of $0.1-2 \%$ in appendectomy materials. ${ }^{27}$ In its etiology, not only Chron's disease, but also infectious or non-infectious causes such as Yersinia species, sarcoidosis, tuberculosis, foreign body reactions, schistosomiasis, actinomycosis and eosinophilic infiltration. ${ }^{28,29}$ In our study, granulomatous appendicitis $1(0.05 \%)$, eosinophilic infiltration $2(0.1 \%)$, foreign body reaction $2(0.1 \%)$ and parasite infestation were observed in 1 $(0.05 \%)$ patient. However, no granulomatous formation was 
detected in eosinophilic infiltration and parasite infestation. Carcinoid tumor (neuroendocrine tumor) is the most common primary malignant lesion of the appendix and constitutes $60 \%$ of all appendix tumors. ${ }^{30}$ Carcinoid tumor is detected in $0.3-0.9 \%$ of appendectomy specimens. ${ }^{31}$ It frequently affects young patients and it occurs between ages of 32 and 42.2 years. ${ }^{32,33}$ Carcinoid tumors of the appendix are generally small in size, benign in character, and their metastases occur less than $2 \%$, and tumor sizes are smaller than $1 \mathrm{~cm}$ in $70-95 \%$ of them. ${ }^{34}$ In our study, carcinoid tumor (neuroendocrine tumor) was detected in $2(0.1 \%)$ patients, and the ages of the patients were 27 and 32 years. The findings were consistent with the literature. Tumors of both patients were well differentiated. Tumor sizes were 3 and $4 \mathrm{~mm}$ and invasion of muscularis propria was detected. Neither of them had lymphovascular and perineural invasion.

\section{Conclusion}

Although acute appendicitis is a disease classified as benign and its surgery is a daily surgery, unexpected histopathological findings can be detected in the examination of appendectomy specimens. The variety of these findings can range from premalignant lesions to malignancies. It should be noted that the histopathological evaluation of appendectomy materials is a guide for the diagnosis and treatment of additional diseases present in the patient.

\section{Ethics}

Ethics Committee Approval: Ethics committee approval was not obtained because it was a retrospective study.

Informed Consent: Informed consent was obtained from all participants for surgery.

Peer-review: Internally peer reviewed.

\section{Authorship Contributions}

Surgical and Medical Practices: U.U., R.G., K.G., Concept: U.U., M.T., Design: R.G., D.A., Data Collection or Processing: M.T., D.A., Analysis or Interpretation: R.G., M.T., D.A.,Literature Search: U.U., R.G., K.G., Writing: U.U., R.G.

Conflict of Interest: No conflict of interest was declared by the authors.

Financial Disclosure: The authors declared that this study received no financial support.

\section{References}

1. Yilmaz M, Akbulut S, Kutluturk K, Sahin N, Arabaci E, Ara C, Yilmaz S. Unusual histopathological findings in appendectomy specimens from patients with suspected acute appendicitis. World J Gastroenterol 2013;19:4015-4022.

2. Körner H, Söndenaa K, Söreide JA, Andersen E, Nysted A, Lende $\mathrm{TH}$, Kjellevold $\mathrm{KH}$. Incidence of acute nonperforated and perforated appendicitis: age-specific and sex-specific analysis. World J Surg 1997;21:313-317.

3. Baird DLH, Simillis C, Kontovounisios C, Rasheed S, Tekkis PP. Acute appendicitis. BMJ 2017;357:1703.

4. Addiss DG, Shaffer N, Fowler BS, Tauxe RV. The epidemiology of appendicitis and appendectomy in the United States. Am J Epidemiol 1990;132:910-925.

5. Marudanayagam R, Williams GT, Rees BI. Review of the pathological results of 2660 appendicectomy specimens. J Gastroenterol 2006;41:745-749.

6. Akbulut S, Tas M, Sogutcu N, Arikanoglu Z, Basbug M, Ulku A, Semur H, Yagmur Y. Unusual histopathological findings in appendectomy specimens: a retrospective analysis and literature review. World J Gastroenterol 2011;17:1961-1970.

7. Limaiem F, Arfa N, Marsaoui L, Bouraoui S, Lahmar A, Mzabi S. Unexpected Histopathological Findings in Appendectomy Specimens: a Retrospective Study of 1627 Cases. Indian J Surg 2015;77:1285-1290.

8. Şahin S, Seçkin S. Histopathological Diagnoses Detected in Appendectomy Specimens. Firat Med J 2018;23:23-27.

9. Orbatu D, Ekmekci S, Alaygut D, Sayan A, Özdemir T, Küçük Ü. Incidental Findings on Routine Histopathological Examination: Analysis of Pediatric Appendectomy Specimens. Behcet Uz Cocuk Hast Derg 2019;9:211-215.

10. Gaitán HG, Reveiz L, Farquhar C, Elias VM. Laparoscopy for the management of acute lower abdominal pain in women of childbearing age. Cochrane Database Syst Rev 2014:CD007683.

11. Patel AV, Friedman M, MacDermott RP. Crohn's disease patient with right lower quadrant abdominal pain for 20 years due to an appendiceal neuroma (Fibrous obliteration of the appendix). Inflamm Bowel Dis 2010;16:1093-1094.

12. Aydın O, Aydın G, Pircanoğlu EM, Civelek S, Pehlivanlıŏlu F, Karaca G. A Rare Appendiceal Anomaly: Agenesis of the Vermiform Appendix. KÜ Tip Fak Derg 2017;19:37-40.

13. Erdoğan O, Arıcı C, Çolak T. Duplication of the appendix. Ulus Travma Acil Cerrahi Derg 2000;6:66-68.

14. Akbulut S, Koc C, Kocaaslan H, Gonultas F, Samdanci E, Yologlu S, Yilmaz S. Comparison of clinical and histopathological features of patients who underwent incidental or emergency appendectomy. World J Gastrointest Surg 2019;11:19-26.

15. Dincel O, Goksu M, Turk BA, Pehlivanoglu B, Isler S. Unexpected findings in the routine histopathological examinations of appendectomy specimens A retrospective analysis of 1,970 patients. Ann Ital Chir 2017;88:519-525.

16. Emre A, Akbulut S, Bozdag Z, Yilmaz M, Kanlioz M, Emre R, Sahin N. Routine histopathologic examination of appendectomy specimens: retrospective analysis of 1255 patients. Int Surg 2013;98:354-362.

17. Coulier B, Pierard F, Malbecq S. Appendicular diverticulitis in an Amyand's hernia. JBR-BTR 2010;93:114.

18. Manzanares-Campillo Mdel C, Pardo-García R, Martín-Fernández J. Appendicular pseudodiverticula and acute appendicitis. Our 12-year experience. Rev Esp Enferm Dig 2011;103:582-585.

19. Collins DC. A study of 50,000 specimens of the human vermiform appendix. Surg Gynecol Obstet 1955;101:437-445.

20. Hellsten S. Mucocele and carcinoma of the appendix. Acta Pathol Microbiol Scand 1964;60:473-482.

21. Agrusa A, Romano G, Galia M, Cucinella G, Sorce V, Di Buono G, Agnello F, Amato G, Gulotta G. Appendiceal mucinous neoplasms: an uncertain nosological entity. Report of a case. G Chir 2016;37:86-89.

22. Demetrashvili Z, Chkhaidze M, Khutsishvili K, Topchishvili G, Javakhishvili T, Pipia I, Qerqadze V. Mucocele of the appendix: case report and review of literature. Int Surg 2012;97:266-269.

23. Rouchaud A, Glas L, Gayet M, Bellin MF. Appendiceal mucinous cystadenoma. Diagn Interv Imaging 2014;95:113-116. 
24. MacGillivray JB. Mucosal metaplasia in the appendix. J Clin Pathol 1972;25:809-811.

25. Younes M, Katikaneni PR, Lechago J. Association between mucosal hyperplasia of the appendix and adenocarcinoma of the colon. Histopathology 1995;26:33-37.

26. Meyerding EV, Bertram HF. Nonspecific granulomatous inflammation (Crohn's disease) of the appendix: a case report. Surgery 1953;34:891-894.

27. Bronner MP. Granulomatous appendicitis and the appendix in idiopathic inflammatory bowel disease. Semin Diagn Pathol 2004;21:98-107.

28. AbdullGaffar B. Granulomatous diseases and granulomas of the appendix. Int J Surg Pathol 2010;18:14-20.

29. Türkcü G, Keleş A, Alabalık U, Soylu B, İbiloğlu İ, Dursun FŞ, Oğuz A, Büyükbayram H. 1829 apendektomi materyalinin retrospektif olarak değerlendirilmesi. Harran Üniversitesi Tip Fakültesi Dergisi 2015;12:193199.
30. Connor SJ, Hanna GB, Frizelle FA. Appendiceal tumors: retrospective clinicopathologic analysis of appendiceal tumors from 7,970 appendectomies. Dis Colon Rectum 1998;41:75-80.

31. Goede AC, Caplin ME, Winslet MC. Carcinoid tumour of the appendix. Br J Surg 2003;90:1317-1322.

32. Roggo A, Wood WC, Ottinger LW. Carcinoid tumors of the appendix. Ann Surg 1993;217:385-390.

33. Modlin IM, Sandor A. An analysis of 8305 cases of carcinoid tumors. Cancer 1997;79:813-829.

34. Shapiro R, Eldar S, Sadot E, Venturero M, Papa MZ, Zippel DB. The significance of occult carcinoids in the era of laparoscopic appendectomies. Surg Endosc 2010;24:2197-2199. 